\title{
Chemical composition and minerals in pyrite ash of an abandoned sulphuric acid production plant
}

Marcos L. S. Oliveira ${ }^{a}$; Colin R. Ward ${ }^{b}$; Maria Izquierdo ${ }^{c}$; Carlos H. Sampaio ${ }^{d}$; Irineu A.S. de Brum $^{\text {d }}$; Rubens M. Kautzmann ${ }^{\text {g }}$; Sydney Sabedot ${ }^{\mathrm{g}}$; Xavier Querol ${ }^{\mathrm{e}}$; Luis F. O. Silva ${ }^{\text {f,g,h }}$

${ }^{a}$ Development Department of Touristic Opportunities, Catarinense Institute of Environmental Research and Human Development - IPADHC, Capivari de Baixo, Santa Catarina, Brazil

${ }^{\mathrm{b}}$ School of Biological, Earth and Environmental Sciences, University of New South Wales, Sydney, NSW 2052, Australia.

${ }^{\mathrm{c}}$ British Geological Survey, Keyworth, Nottingham NG12 5GG, UK

${ }^{d}$ Universidade Federal do Rio Grande do Sul, Escola de Engenharia, Departamento de Metalurgia, Centro de Tecnologia, Av. Bento Gonçalves, 9500, Bairro Agronomia, CEP: 91501-970, Porto Alegre, RS, Brazil

${ }^{\mathrm{e}}$ Institute of Environmental Assessment and Water Research, Jordi Girona 18-26, 08034 Barcelona, Spain

${ }^{\mathrm{f}}$ Environmental Science and Nanotechnology Department, Catarinense Institute of Environmental Research and Human Development - IPADHC, Capivari de Baixo, Santa Catarina, Brazil. felipeqma@hotmail.com

g Centro Universitário La Salle, Mestrado em Avaliação de Impactos Ambientais em Mineração. Victor Barreto, 2288 Centro 92010-000 - Canoas, RS - Brasil.

${ }^{\text {h }}$ Centro Universitário Univates, Programa de Pós Graduação Ambiente e Desenvolvimento. Rua Avelino Tallini, 171, Universitário 95900-000 - Lajeado, RS - Brasil. lfsoliveira@univates.br

\begin{abstract}
The extraction of sulphur produces a hematite-rich waste, known as roasted pyrite ash, which contains significant amounts of environmentally sensitive elements in variable concentrations and modes of occurrence. Whilst the mineralogy of roasted pyrite ash associated with iron or copper mining has been studied, as this is the main source of sulphur worldwide, the mineralogy, and more importantly, the characterization of nanoparticles, in coal-derived roasted pyrite ash remain to be resolved. In this work we provide essential data on the chemical composition and nanomineralogical assemblage of roasted pyrite ash. XRD, HR-TEM and FE-SEM were used to identify a large variety of minerals of anthropogenic origin. These phases result from highly complex chemical reactions occurring during the processing of coal pyrite of southern Brazil for sulphur extraction and further manufacture of sulphuric acid. Iron-rich nanoparticles within the ash may contain high proportions of toxic elements such as As,
\end{abstract}


$\mathrm{Se}, \mathrm{U}$, among others. A number of elements, such as $\mathrm{As}, \mathrm{Cr}, \mathrm{Cu}, \mathrm{Co}, \mathrm{La}, \mathrm{Mn}, \mathrm{Ni}, \mathrm{Pb}, \mathrm{Sb}, \mathrm{Se}, \mathrm{Sr}, \mathrm{Ti}, \mathrm{Zn}$, and $\mathrm{Zr}$, were found to be present in individual nanoparticles and nanominerals (e.g. oxides, sulphates, clays) in concentrations up to $5 \%$. The study of nanominerals in roasted pyrite ash from coal rejects is important to develop an understanding on the nature of this by-product, and to assess the interaction between emitted nanominerals, ultra-fine particles, and atmospheric gases, rain or body fluids, and thus to evaluate the environmental and health impacts of pyrite ash materials.

Keywords: coal rejects, sulphuric acid production, nanomineral impacts, potentially hazardous elements.

\section{INTRODUCTION}

Coal has been used in Brazil as solid fuel for thermoelectric generation for nearly 80 years (Pires and Querol, 2004). According to the local coal industry syndicate of Santa Catarina State, the average run-of-mine coal production is 6 million tonnes/year, from which 3.5 million tonnes/year are rejected and disposed of in landfills (Marcello et al., 2008). Brazilian coal is characterised by high proportions of sulphide minerals, pyrite and marcasite (Galatto et al. 2009; Lattuada et al. 2009; Marcello et al. 2008; Silva et al. 2009), and therefore the rejects from coal cleaning operations can be regarded as potential sources of sulphur.

In the early $1950 \mathrm{~s}$, the importance of sulphur increased in the world, primarily due to primarily an increasing demand for phosphate processing for agricultural purposes. In this context the Brazilian government, through Decree-Law No 631 of 16.06 .1969 and in order to obtain benefit from pyrite in the coal, decided to create the Catarinense Carbochemical Industry S/A- (Indústria Carboquímica Catarinense or ICC in Portuguese), with operations based in the city of Imbituba (Figure 1).

The ICC plant used a Batac jig to produce around 76 tonnes/hour of pyrite concentrate ( $\approx 50 \%$ sulphur) from coal cleaning reject material typically containing 0.5 to $5 \%$ sulphur (Silva et al., 2010a). The pyrite concentrate was then heated to $900^{\circ} \mathrm{C}$ to extract the sulphur (as $\mathrm{SO}_{2}$ which was converted to sulphuric acid), leaving a residue consisting basically of iron oxide (mainly hematite) and containing $<3 \%$ sulphur on average (Gaspetro, 2010). In theory, this process is environmentally clean; the hematiterich waste, known as roasted pyrite ash, can be used as an iron ore in the steel, brick, paint and cement 
industries (Pérez-López et al., 2009). However, the iron oxide-rich residue contains significant concentrations of potentially polluting elements (e.g., $\mathrm{Cu}, \mathrm{S}, \mathrm{Zn}, \mathrm{Pb}$ and $\mathrm{As}$ ) that can be very mobile under environmental conditions, and this serves to reduce its applicability. Another residue from the overall process is phosphosgypsum (PG), a by-product of phosphate rock processing by wet-chemical treatment with sulphuric acid produced from the pyritic feedstock. This material contains significant concentrations of impurities such as $\mathrm{P}_{2} \mathrm{O}_{5}$ and $\mathrm{F}$ (from the apatite in the phosphate rock), as well as radioactive elements, organic substances, secondary nanominerals, and ultrafine particles containing potentially toxic metals and metalloids (Silva et al., 2010a).

Use of the ICC process served to decontaminate the coal mining area, avoiding for example the formation of acid mine drainage. However, on January 17, 1994, through Resolution No. 109, the Executive Committee of the National Privatization Program approved the closure of the Catarinense S/A - ICC coal industry (Gaspetro, 2010). Wastes from the process nevertheless still remain, stored in deposits located approximately 1 to $2 \mathrm{~km}$ from the Atlantic Ocean (Fig. 1).

In a risk analysis by the regional government the ICC sulphuric acid plant in the Imbituba city industrial complex was identified as having residues with a poorly-known chemical nature, and about which little information was available on the threat posed to the environment. A program of continuous monitoring and control was therefore required during emplacement, construction and operation. However, the company owning the industrial complex declared bankruptcy around twenty years ago and the site was suddenly abandoned. Many waste storage sites in Brazil are more vulnerable than other retention structures because of their location (in Santa Catarina State often situated near sensitive aquatic ecosystems), their unstable nature, and a poor to non-existent maintenance program (especially after closure of mining activities).

Other countries, such as Spain, France, Italy, Romania, Turkey and the USA, have produced sulphuric acid from pyrite, but there is little work in the current literature that attempts to assess the environmental risks associated with the by-products of this process. Pérez-López et al. (2009) undertook sequential extraction procedures on roasted pyrite ashes from Southern Spain to determine the mobility of a number of metals and asses the polluting capacity. Lin and Qvafort (1996) studied the content and mode of occurrence of $\mathrm{Zn}, \mathrm{Fe}, \mathrm{Cu}, \mathrm{Pb}$ and $\mathrm{Cd}$ in roasted pyrite ash by means of SEM, EPMA and XRD and also conducted leaching tests to assess element their mobility. Whilst those studies dealt with roasted pyrite ash from processing sulphide ores, the present study has examined ashes derived from 
coal cleaning rejects. The different nature and purity of the pyrite ores may mean that roasted pyrite ash derived from coal preparation rejects has different characteristics to those reported for other such residues. To our knowledge, information regarding the composition and mineralogy of pyrite ash from coal cleaning rejects is limited. The present study has also identified a range of previously unrecognized nanominerals and ultra-fine particles, which that may contain elements with potential for adverse environmental or human health impacts.

The research discussed in this paper represents a preliminary study, aimed at evaluating the occurrence of nanoparticles in the wastes and whether they contain potentially toxic elements, by comparing the iron oxide waste obtained from heating of the pyrite to other wastes collected from the ICC site. It is hoped that the results will serve as a reference for similar studies in other countries where sulphuric acid has been produced from pyrite (Kawatra et al., 2002; Pérez-López et al., 2009; Rico et al., 2008a and 2008b; Zeilinski et al., 2010). Given the extent of production of roasted sulphides and the limited literature available on their potential impact on the environment, the information presented in this paper (especially with regard to nanoparticles) may be of value in designing remediation strategies for roasted pyrite ash storage systems distributed around the world (Gupta et al., 1996; Kawatra et al., 2002; Lin and Qvarfort, 1996; Pérez-López et al., 2009; Salomons, 1995; Zouboulis et al., 1993).

\section{MATERIALS AND METHODS}

\subsection{Sampling}

Field work in this study area was performed during 2009 (June and November) and 2010 (February, April and July). Previous studies based on boreholes from the studied area revealed an evident homogeneity in the pyrite ash (Gaspetro, 2010; Silva et al., 2010a). Five samples of roasted pyrite ash (ca. 3-kg), one sample of the pyrite concentrate (ca. 3-kg), and four samples of phosphogypsum were collected from various locations in Imbituba City, Santa Catarina, Brazil (Fig. 1). Due to inadequate disposal of the various by-products of the process, contamination of the pyrite concentrate and ash samples with traces of phosphogypsum may also have been included. 
The samples were collected using a polypropylene shovel, and were subsequently transferred to clean polypropylene bags. All samples were dried at a temperature $<40{ }^{\circ} \mathrm{C}$, homogenized, ground to pass 200 mesh $(<74 \mu \mathrm{m})$, and stored in polypropylene containers in a dry system until required for analysis.

\subsection{Analytical procedures}

Representative portions (approx. $0.5 \mathrm{~g}$ ) of each powdered sample were subjected to X-ray powder diffraction (XRD) analysis at the University of New South Wales using a Philips PW-1830 diffractometer with $\mathrm{Cu} \mathrm{K \alpha}$ radiation. Scanning was carried out from 2 to $60^{\circ} 2 \theta$, with a step interval of $0.04^{\circ}$ and a counting time of 2 seconds per step. The minerals were identified by reference to the ICDD Powder Diffraction File. Quantitative analysis of mineral abundance was carried out using the Siroquant ${ }^{\mathrm{TM}}$ processing software (Taylor, 1991), based on the principles developed by Rietveld (1969), using procedures discussed further by Ward et al. (1999).

Sample digestion for total element concentrations was performed by accurately weighing $0.100 \pm 0.01 \mathrm{~g}$ of size-reduced sample into a vial and adding concentrated $\mathrm{HNO}_{3}$ acid before heating at $80^{\circ} \mathrm{C}$ overnight, the purpose being the digestion of reactive organic phases. This first hot extraction was then centrifuged, the supernatant being transferred to a volumetric flask and the solid residue placed back in the vial, where it was digested by adding $\mathrm{HF}, \mathrm{HNO}_{3}$ and $\mathrm{HClO}_{4}$ concentrated and analytical grade acids, heating closed overnight and then evaporating, the purpose being the digestion of silicate and oxide phases. The dry residue was re-constituted with $\mathrm{HNO}_{3}$ and $\mathrm{MQ}$ water to $100 \mathrm{~mL}$ of $5 \% \mathrm{v} / \mathrm{v}$ $\mathrm{HNO}_{3}$ and stored in HDPE bottles. Reference materials (SARM 19, NIST SRM 1633b), duplicated samples and blanks were all prepared in a similar manner to check accuracy of the analytical and digestion method. The resulting solutions were then analyzed at the Institute of Environmental Assessment and Water Research, Barcelona, by ICP-OES, inductively coupled plasma optical emission spectrometry (Jobin Yvon Ultima 2), to determine the concentrations of major elements, and inductively coupled plasma-mass spectroscopy (ICP-MS; Perkin Elmer Elan 6000) for trace elements.

Field-emission scanning electron microscopy (FE-SEM, for minerals/particles between 0.5 and $80 \mu \mathrm{m}$ ) and high-resolution transmission electron microscopy (HR-TEM for minerals/particles between 0.1 and $500 \mathrm{~nm}$ ) were used to provide direct (real space) visualization of nanoparticles in small amounts of each sample. The morphology, crystal structure, surface topography, and chemical composition of 
ultrafine minerals present in the pyrite ash, phosphogypsum, and concentrated sulphide were investigated using a Zeiss Model ULTRA Plus FE-SEM, with charge compensation for all applications on conductive as well as non-conductive samples, and a JEOL-2010F 200-keV HR-TEM equipped with an Oxford energy dispersive X-ray detector, and a scanning (STEM) unit (Silva et al., 2010b). Geometrical aberrations were measured by HR-TEM and controlled to less than a $\pi / 4$ phase shift of the incoming electron wave over the probe-defining aperture of $14.5 \mathrm{mrad}$. EDS spectra were recorded in TEM image mode, and then quantified by the thin-foil method using ES Vision software to convert Xray counts of each element into atomic or weight percentages. Electron diffraction patterns of the crystalline phases were recorded in SAED (selected area electron diffraction) or MBD (microbeam diffraction) mode, and the $d$ spacings were compared to the International Center for Diffraction Data (ICDD, 2010) inorganic compound powder diffraction file (PDF) database to identify the crystalline phases.

Suspensions for FE-SEM examination were prepared using hexane, acetone, dichloromethane, and methanol to prevent possible mineralogical changes in individual solvents (Silva et al., 2011; Cornell and Schwertmann, 2003; Ribeiro et al., 2010). The suspension was stirred for $\sim 1 \mathrm{~min}$ and subsequently pipetted onto lacy carbon films supported by $\mathrm{Au}$ or $\mathrm{Cu}$ grids (depending of particle composition in study). The suspension was then left to evaporate before inserting the sample into the FE-SEM and HR-TEM. The solvent dissolves the "binder" material and breaks up aggregates to provide physically separated individual particles amenable for placement on electron grids. This method may lead to agglomeration, but is a widely used procedure, with applications including analysis of metal sulphates (Giere et al., 2006; Quispe et al., 2012). Before FE-SEM and STEM analysis, the TEM specimen holder was cleaned with a Gatan Advanced Plasma System (Model 950) to minimize contamination. A drift-correction system was used for the STEM-EDS mapping.

\section{RESULTS}

\subsection{Mineralogy from XRD analysis}

The mineralogy of the pyrite concentrate and roasted pyrite ash, as indicated by Siroquant processing of the X-ray diffraction data, is given in Table 1. X-ray diffractograms of selected samples are given in Fig. 2. 
The pyrite concentrate (sample IM-05) consists mainly of pyrite $\left(\mathrm{FeS}_{2}\right)$ and iron sulphate minerals such as szomolnockite $\left(\mathrm{FeSO}_{4} \cdot \mathrm{H}_{2} \mathrm{O}\right)$ and coquimbite $\left(\mathrm{Fe}_{2}\left(\mathrm{SO}_{4}\right)_{3} \cdot 9 \mathrm{H}_{2} \mathrm{O}\right)$, together with a significant proportion of gypsum $\left(\mathrm{CaSO}_{4} \cdot 2 \mathrm{H}_{2} \mathrm{O}\right)$ and small proportions of quartz and kaolinite (Table 1 and Fig. 2). Rao and Gluskoter (1973) describe coquimbite and szomolnockite as oxidation products of pyrite in coals from the Illinois Basin, developed after exposure to the atmosphere with storage. A similar process probably occurred in the sulphide concentrate of the present study at the waste disposal site. Based on studies of Santa Catarina coals by Oliveira et al. (2012), the quartz and kaolinite in the concentrate were probably also present in the original coal cleaning rejects. The gypsum in the pyrite concentrate was probably originated from one or both of the following processes: (1) interaction between calcite in the coal cleaning residues and sulphuric acid produced by oxidation of the pyrite in the same material; (2) contamination from the phosphogypsum deposits also found at the site (Fig. 1B).

The roasted pyrite ash (samples IM-10 to IM-14) consists dominantly of hematite $\left(\mathrm{Fe}_{2} \mathrm{O}_{3}\right)$, together in some cases with magnetite $\left(\mathrm{Fe}_{3} \mathrm{O}_{4}\right)$, gypsum and a small proportion of quartz. As suggested above for the pyrite concentrate, contamination from phosphogypsum at the disposal site may account for the occurrence of gypsum in the samples. The absence of kaolinite can be attributed to its thermal decomposition at temperatures $\approx 900^{\circ} \mathrm{C}$, but a small proportion of illite is present in one of the ash samples. Although coquimbite and szomolnockite are absent, traces (1-3\%) of jarosite were found in most of the pyrite ash samples.

XRD analysis of the phosphogysum samples showed that this material consists dominantly of gypsum, with traces $(<1 \%)$ of quartz and in some cases anatase. The phosphogypsum also contains a small proportion of material with the crystal structure of chukhrovite, although this cannot be quantified as that particular mineral is not in the current Siroquant database. For that reason mineralogical data on the phosphogypsum have not been included in Table 1. Crystalline material with similar composition and XRD pattern to that of chukhrovite has been described in other filter cakes produced during manufacture of phosphoric acid (Frazier et al., 1977; Mathew et al., 1981), formed by interaction of acid with phosphate ore. Rare earth elements (REE) and Y may also be incorporated into the structure of this material.

\subsection{Major element chemistry}


The concentrations of the major elements in the pyrite concentrate and ash samples inferred from the XRD data, based on the proportion and stoichiometric composition of the minerals, are listed in Table 2. The observed concentrations of the major elements (except for $\mathrm{Si}$ ) and the trace elements in all the samples studied, as determined by ICP analysis, are reported in Table 3.

Iron is the major constituent of the roasted pyrite ash, with concentrations of 50 to $55 \%$. These are equivalent to $\mathrm{Fe}_{2} \mathrm{O}_{3}$ concentrations of between 73 and $78 \%$. Minor proportions of residual sulphur (up to $3 \%$, or up to $8 \%$ if expressed as $\mathrm{SO}_{3}$ ) and $\mathrm{Al}\left(1-2 \%\right.$; equivalent to $\left.2-4 \% \mathrm{Al}_{2} \mathrm{O}_{3}\right)$ are also present. The presence of $\mathrm{S}(0.5-3 \%)$ in the roasted pyrite ash indicates that, despite its iron-rich composition, this material cannot be reused in the metallurgical industry. The pyrite concentrate has a lower proportion of iron $(25 \%)$ but a much higher proportion of sulphur $(27 \%)$, together with a small proportion of calcium (3.8\%). These are equivalent to $35.8 \% \mathrm{Fe}_{2} \mathrm{O}_{3}, 67.5 \% \mathrm{SO}_{3}$ and $5.3 \% \mathrm{CaO}$, respectively.

The inferred percentages of the various elements for the pyrite concentrate sample in Table 2 are of a similar order of magnitude to those determined for the same sample by chemical analysis (Table 3 ). The relatively minor differences in each case may reflect sampling inconsistencies, and also the inherent errors associated with the XRD analysis. The percentages of $\mathrm{Ca}$ and $\mathrm{S}$ inferred from the XRD data (Table 2), especially the relatively high values for sample IM-10, are also similar to those of the respective samples determined by chemical analysis (Table 3). However, the proportion of Fe for the pyrite ash samples is somewhat higher in Table 2 (56-65\%) than in Table 3 (51-55\%).

Silicon was not determined in the chemical analysis, due to volatilisation and loss of silica during digestion. However, the difference between the sum of the oxide percentages derived from the major element data in Table 3 (see above) and 100\% suggests the possible occurrence of around $10-20 \% \mathrm{SiO}_{2}$ $(4.7-9.5 \% \mathrm{Si})$ in the pyrite ash samples. Such a value does not seem to be consistent with the results reported in Table 2, where the inferred percentage of silicon is less than $2 \%$, or with the XRD data (Table 1), which indicate 1.4 to $3.2 \%$ quartz in the pyrite ash samples. This might suggest the occurrence of minor proportions of amorphous (alumino)silicates along with the quartz. Although this is not evident on the X-ray diffractograms (Fig. 2), amorphous aluminosilicate material has been observed by other techniques used in this study (section 3.2).

As might be expected from its mineralogy, the phosphogypsum samples consist mainly of $\mathrm{Ca}$ and $\mathrm{S}$ (Table 3). The percentages of these components are close to the stoichiometric percentages of $\mathrm{Ca}$ 
and $\mathrm{S}$ in gypsum (23.3 and 18.6\%, respectively). Minor proportions $(<1 \%)$ of $\mathrm{Al}, \mathrm{Fe}, \mathrm{P}$ and Ti are also present, probably associated with phases such as chukhrovite and anatase, and possibly hematite, at trace levels in the phosphogypsum material.

\subsection{Trace element concentrations}

The concentrations of various trace elements in the samples are given in Table 3. For comparison, Table 3 also lists the range of element concentrations in Santa Catarina coal cleaning rejects (Silva et al., 2011), and in roasted ashes derived from pyrite-bearing ores (Li and Qvafort, 1996; PerezLopez et al., 2009).

As might be expected, the roasted ash samples have relatively high concentrations of elements typically commonly associated with pyrite and other phases commonly found in coals (Finkelman and Gross, 1999), especially $\mathrm{As}, \mathrm{Co}, \mathrm{Cu}, \mathrm{Mo}, \mathrm{Ni}, \mathrm{Pb}, \mathrm{V}$ and $\mathrm{Zn}$. These elements are also relatively abundant in the pyrite concentrate (IM-05), but often have somewhat lower concentrations in the concentrate than in the roasted ash materials.

The roasted ash samples in the present study appear to have lower concentrations of a number of trace elements when compared to similar ashes derived from non-coal pyritic ores (Table 3). The concentrations of $\mathrm{As}, \mathrm{Bi}, \mathrm{Cd}, \mathrm{Cu}, \mathrm{Pb}, \mathrm{Sn}$ and $\mathrm{Zn}$, for example, are at least one order of magnitude lower than those reported for equivalent ore-derived materials (Lin and Qvafort, 1996; Perez-Lopez et al., 2009), whilst $\mathrm{Co}, \mathrm{Cr}, \mathrm{Ni}, \mathrm{Sb}$ and $\mathrm{V}$ fall in the lower part of the ore-derived range. The fact that the samples in the present study were derived from a less pure pyrite (obtained from coal cleaning rejects) probably accounts for the lower metal loadings, and therefore the environmental implications may be less significant. When compared to the relevant parent material, i.e. coal cleaning rejects reported by Silva et al. (2011), it is apparent that the roasted pyrite ashes are particularly enriched in elements typically associated with sulphides in coal, e.g. As, $\mathrm{Cu}, \mathrm{Ni}, \mathrm{Pb}, \mathrm{Sb}, \mathrm{Se}, \mathrm{Tl}$ and $\mathrm{Zn}$ (Finkelman and Gross, 1999).

The phosphogypsum samples contain much higher concentrations of a number of elements than the roasted pyrite ashes. These include $\mathrm{Ba}$ and $\mathrm{Sr}$, which are probably associated with the very abundant $\mathrm{Ca}$ in the phosphogypsum, but also the REE and $\mathrm{Y}$, as well as $\mathrm{Hf}, \mathrm{Nb}, \mathrm{Th}, \mathrm{U}$ and $\mathrm{Zr}$. Along with the $\mathrm{Ca}$, 
$\mathrm{Sr}$ and $\mathrm{Ba}$, the REE and other trace elements were probably derived mainly from the phosphate rock treated at the site, and not from the pyrite-rich feedstock used for acid production.

Although a roasted pyrite ash, sample IM-10 also shows somewhat higher concentrations of a number of these elements, with a ten-fold increase in $\mathrm{Ca}, \mathrm{P}, \mathrm{S}, \mathrm{Be}, \mathrm{REE}, \mathrm{Se}, \mathrm{Sr}$, Ta and Y concentrations compared to the other roasted ash samples. The XRD data (Table 1) shows around 16\% gypsum in this particular sample; together with the anomalous trace element concentrations, this suggests a greater degree of contamination for this sample by phospogypsum, compared to the other roasted ash materials.

As pointed out by Seredin and Dai (2012), the rare earth elements plus yttrium (REY) play a key role in the manufacture of materials and products for a wide range of purposes, including electronic and optical equipment, superconductors, and electric power generation and storage facilities. Coals and coal ashes from particular areas, mostly in China, eastern Russia and Tajikistan, with high concentrations of REE, have been identified as potential economic sources of these elements (Seredin and Dai, 2012), with recovery as a by-product of coal utilisation. Total REE concentrations in coal ashes reported by Seredin and Dai (2012) are up to 8000 ppm, but are mostly between 1000 and 2000 ppm. The total concentration of REE in the phosphogypsum samples of the present study is around $5000 \mathrm{ppm}$, with the light REE, such as $\mathrm{La}, \mathrm{Ce}, \mathrm{Pr}$ and $\mathrm{Nd}$, having the highest concentrations. The occurrence of the REE in a gypsum-based material, moreover, may allow lower-cost recovery than from silicate-rich coal combustion products. Such recovery, if technically and economically feasible, may provide a basis for beneficial use of the phosphogypsum residues at the Santa Catarina site, although further evaluation of the possibilities is beyond the scope of the present paper.

\section{MINOR PHASES AND NANOPARTICLES IN PYRITE AND PYRITE ASH}

Table 4 provides a list of primary and secondary minerals that have been identified in the pyrite concentrate and pyrite ash samples, based on a combination of FE-SEM/EDS and HRTEM/STEM/EDS/SEAD/MBD/FFT data. Most of those in the pyrite concentrate (sample IM-05) have also been detected in other samples of coal and coal cleaning rejects (Silva et al., 2010c, 2011; Oliveira et al., 2012). With the exception of the minerals indicated for the respective samples in Table 1 (e.g. pyrite, gypsum, hematite, magnetite, jarosite), most of the phases in Table 4 are at concentrations well below the limit of detection by XRD techniques. 
SAED/MBD and especially FFT were used to provide more specific identification of phases in Table 4 having identical or near-identical chemical compositions. This enabled, for example, distinction between calcite and aragonite (both $\mathrm{CaCO}_{3}$ ), pyrite, marcasite, and pyrrhotite (Fe sulphides), $\mathrm{Fe}$ sulphates (e.g. rozenite and melanterite), Fe oxides (e.g. hematite, magnetite, wustite, and maghemite), and K-bearing silicates (e.g. illite, K-feldspar). The combination of FE-SEM, STEM-EDS mapping, and HR-TEM analysis may thus have wide application in the identification of nanominerals and ultra-fine particles in pyrite ashes and similar materials.

Several rare minerals (e.g. cerianite and rosenbergite) were detected by HRTEM/EDS/SAED/FFT techniques. These may represent precipitates formed during wet $\mathrm{H}_{2} \mathrm{SO}_{4(\mathrm{l})}$ processing of the phosphate ore, as apatite-rich rocks often contain monazite (Figure 6B). Such a process would result in the formation of the rare F-bearing and REE-bearing nanominerals and ultrafine particles, either crystalline or amorphous, which may pose serious problems for safe ash utilization and disposal.

\subsection{Elements and nanoparticles in mineral phases}

The electron beam methods used in the present study also provide further information on the occurrence and speciation of potentially hazardous elements that may be incorporated (often at very low concentrations) into the structure of some of these minerals. For example, the nanopyrite grains detected by HR-TEM/SAED/EDS in sample IM-05 were found to contain rounded crystalline and/or amorphous nanoparticles consisting of As (2.3-4.9 wt\%), Cu (1.5-2.6 wt\%), Hg (0.7-1.8 wt\%), Ni (0.8-1.5 wt\%), and $\mathrm{Se}(1.4-2.9 \mathrm{wt} \%)$.

The roasted pyrite ashes contain abundant hematite and magnetite, mixed with a carbonaceous matrix (Fig 3A). This fact is coming from our EDS spectrum result and this assemblage is consistent with heating pyrite-rich coal cleaning rejects as part of the sulphur extraction process. FE-SEM and HRTEM/SAED/MBD images and supporting EDS data indicate the presence of additional fine crystalline phases, such as Fe-rich oxide or spinel. Fast Fourier transform (FFT) and spectroscopic techniques (e.g. electron energy-loss spectroscopy and EDS) have been used to support the identification of many nanominerals in the pyrite ashes. For example, Figure 3B shows spherical nanohematite identified in sample IM14. A complex assemblage of this Fe-oxide with residual amorphous silicate can be observed 
(Figure 3B). It is worth mentioning the ability of this assemblage system to retain Mo and $\mathrm{Cu}$ in the particle/mineral structure.

Traces of nanopyrite (Fig. 4A) and nanosphalerite (Fig. 4C) have been identified in residual particles of non-oxidized sulphides, along with Fe-nanosulphate (e.g jarosite (Figure 4B) and schwertmannite), and Fe-nanohydroxides (mainly minerals of the gibbsite, brucite, and goethite groups, containing $\mathrm{As}, \mathrm{Cd}, \mathrm{Cr}, \mathrm{Pb}$, among other elements) appear as accessory minerals. The typical high porosity of these wastes (Kawatra et al., 2002; Pérez-López et al., 2009; Rutherford et al., 1994; Silva et al., 2010a; Zielinski et al., 2010) favours continuous atmospheric oxygen uptake and the release of metals associated with sulphides (oxidizable fraction), which also precipitate as sulphate salts (e.g. ultrafine jarosite pseudomorph in Fig. 4B).

Sphalerite (Fig. 4C), kaolinite (Fig. 5A), and nanospheres containing quartz (Fig. 5C) are also present. Many of the glassy aluminosilicate spheres have a partial or total C-based nanocoating (Fig. 5B). These aggregates are typically between $2 \mathrm{~nm}$ and $1 \mu \mathrm{m}$ in size, although smaller soot aggregates $(<1 \mathrm{~nm})$ were also found in the pyrite ash samples showing interaction with nanohematite crystals (Silva et al., 2012).

Abundant heavy metals and metalloids, such as As, $\mathrm{Cr}, \mathrm{Cu}, \mathrm{Co}, \mathrm{La}, \mathrm{Mn}, \mathrm{Ni}, \mathrm{Pb}, \mathrm{S}, \mathrm{Sb}, \mathrm{Se}, \mathrm{Sr}, \mathrm{Ti}$, $\mathrm{Zn}$, and $\mathrm{Zr}$, at concentrations up to 5\%, are indicated by the EDS data in individual nanoparticles and nanominerals (e.g. oxides, sulphates, and clays). These elements appear to be bound to the nanominerals concerned. In particular, the $\mathrm{Al}, \mathrm{C}, \mathrm{Ni}, \mathrm{Mg}$, and $\mathrm{Zr}$-bearing particles are typically sub-micron in size (250-350 nm) and spherical in form. The chemical composition and morphology of the sub-micron spheres identified in the pyrite ashes (e.g. Fig. 7A) reveal the common presence of aluminosilicate glass, ferrian spinel, hematite, kaolinite, magnetite, mullite, and quartz.

The primary ultrafine particles generated directly from this industrial process are mostly submicrometer $(0.1$ to $700 \mathrm{~nm})$ agglomerates of amorphous solid phases containing several hazardous elements (Figs. 6A and 7). They include nanominerals and ultra-fine particles containing $\mathrm{As}, \mathrm{Cd}, \mathrm{Cu}$, $\mathrm{Mo}, \mathrm{Pb}, \mathrm{Se}, \mathrm{U}$, and many other elements. In addition, an As-bearing phase has been identified in many of the pyrite ash pellets, occurring as nano-scale particles at the grain boundaries of feldspar crystals in the pyrite ashes. The surrounding areas of aluminosilicate glass consist essentially of $\mathrm{Al}, \mathrm{Fe}, \mathrm{Mg}, \mathrm{Si}, \mathrm{Ti}$, and $\mathrm{Zr}$ (as well as low concentrations of hazardous elements e.g. As, Mo, Pb, and Ni). The Fe- 
FEM/EDS and STEM images clearly demonstrate that at least some of the amorphous nanoparticles, such as the Fe-aluminosilicate particles shown in Figs 6A and 7, posses a heterogeneous microstructure in which $\mathrm{Fe}, \mathrm{Al}, \mathrm{Si}$, hazardous elements, and radioactive elements (in the case of inappropriate phosphogypsum disposal) are not uniformly distributed.

Samples IM-10, IM-11, and IM-14 have higher concentrations of volatile elements (i.e. As, $\mathrm{Hg}$, and Se) compared to other roasted pyrite ash samples. This enrichment could be related to the carbon/char content. Elements such as $\mathrm{As}, \mathrm{Cs}, \mathrm{Mo}, \mathrm{Pb}$ and $\mathrm{Sb}$ could be present as condensates on the surface of the aluminosilicate spheres and amorphous ultra-fine particles (Fig. 6A) from pyrite ash (IM10 and IM 13 respectively). A similar association has been reported in previous studies on coal-fired power stations (Hower et al., 2008; Silva and DaBoit, 2010). Hower et al. (2008) noted that As, Hg, Se, among other elements, were present in 5-nm metal entities within a fullerene-like carbon in a coal fly ash derived from Kentucky coal, demonstrating the potential for such associations in coal fly ashes derived from low- to medium- $\mathrm{C}$ and $\mathrm{S}$ coals. In the present study $\mathrm{As}, \mathrm{Ga}, \mathrm{Ge}, \mathrm{Hg}, \mathrm{Mo}, \mathrm{Pb}, \mathrm{Se}, \mathrm{Sn}, \mathrm{Tl}, \mathrm{V}$, $\mathrm{W}$, among other elements, and $\mathrm{Zn}$ compounds may be emitted to the environment during pyrite ashes formation.

The HR-TEM images, EDS, MBD, FFT, and SAED patterns of the most abundant hazardous volatile elements and nanoparticles in the roasted pyrite ashes show a significant distortion of the Asrich matrix in the vicinity of the crystalline nanoparticles, with a sharp boundary between the ordered and distorted areas. Recognition of amorphous nanoparticles in residual pyrite ashes from the ICC process suggests that other nanoparticles observed in these by-products could have formed as liquids. This is contingent on their thermal stability, which, in turn, is directly related to their chemical composition because $\mathrm{As}, \mathrm{Cu}, \mathrm{Hg}, \mathrm{Ni}$, and $\mathrm{Se}$ can produce phases with low melting temperatures. These results suggest that element-rich nanoparticle-bearing minerals and nanominerals contain amorphous inclusions and porosity that may have changed their composition and form during heating when sulphuric acid was produced from the pyrite.

\section{IMPLICATIONS FOR HUMAN HEALTH}

Anthropogenic nanoparticles are receiving increasing attention due to their unique role as agents of elemental transport and their increased reactivity in geologic systems (Chen et al., 2004; Hochella et 
al., 2008). The behaviour of mineral nanoparticles from pyrite ash in anthropogenic systems is still not well understood, due to a lack of experimental data on their physico-chemical properties. The fine submicrometer to ultrafine size of such particles enables heavy metals to penetrate deeply and easily into the respiratory tract, and translocation of insoluble particles into tissues and the vascular system. Since ultrafine particles are much more inflammogenic per mass dose than larger-size particles (Brown et al., 2001), the inflammatory response of the observed heavy metal particles may be significantly higher than that expected from bulk elemental concentrations (Utsunomiya et al., 2009). Less pronounced sizeeffects are expected from the $0.1-100 \mathrm{~nm}$ size trace metal particles in the pyrite ashes that consist mainly of $\mathrm{As}, \mathrm{Cr}, \mathrm{Pb}, \mathrm{Se}, \mathrm{Sr}, \mathrm{Sn}$, and $\mathrm{Zn}$, among other hazardous elements.

The pyrite ash in the present study contains considerable concentrations of nanopyrite (Fig. 3A), which has been shown to spontaneously generate hydrogen peroxide $\left(\mathrm{H}_{2} \mathrm{O}_{2}\right)$ (Borda et al., 2001; Cohn et al., 2005) and hydroxyl radicals $(\cdot \mathrm{OH})(\mathrm{Cohn}$ et al., 2004) when in contact with in water (e.g. rain). The formation of these reactive oxygen species (ROS) also accounts for recent observations of aqueous pyrite slurries degrading yeast RNA, ribosomal RNA, and DNA (Cohn 2004). In addition, pyrite is thought to form $\mathrm{H}_{2} \mathrm{O}_{2}$ through the iron-catalyzed Haber-Weiss reactions. Water contact in conjunction with atmospheric exposure promotes sulphide oxidation (Devasahayam, 2006; Weber et al., 2006), and consequently the oxidation of pyrite may release to the environment the trace pollutants hosted, typically $\mathrm{As}, \mathrm{Hg}$, $\mathrm{Se}$ or $\mathrm{Pb}$, among others (Finkelman, 1994).

Anthropogenically generated dust, such as that arising from the abandoned sulphuric acid production industry which is the focus of the present study, can result in significant injections of nanominerals and ultrafine particles into the environment. The high-spatial-resolution methods of the present study, using FE-SEM and HR-TEM as the primary probes for both geochemistry and structure, have enabled evaluation of fine-grained particles and potential nanominerals. Sub-micron iron-bearing minerals (especially hematite and magnetite, see Figs 4 and 5B) resulting from anthropogenic activities are of particular interest. Hematite and magnetite particles are known to have a wide range of geochemical reactivity (Madden et al., 2006), including adsorption of ions such as phosphates and arsenates (Waychunas et al., 2005a,b), photochemical reduction in aqueous solution (Sherman, 2005), heterogeneous catalysis (Feng et al., 2004), and acceptance of electrons from microbial respiration. However, hazardous element distribution within individual waste particles is not homogeneous. Such some Fe-oxide nanoparticles exhibit highly crystalline characteristics (e.g. hematite), as confirmed by 
HR-TEM images in which electron diffraction patterns of the crystalline phases were recorded in SAED and FFT (Fig. 3B). They also contain metal-rich and absorbed/condensed sulphur compounds (EDS pattern in Fig. 4B), radionuclide elements when phosphogypsum is present (Fig. 6B), and deleterious metalloids (e.g. As) and metals ( $\mathrm{Cd}, \mathrm{Fe}, \mathrm{Mg}, \mathrm{Pb}, \mathrm{Ti}$, and $\mathrm{Zr}$ ). The speciation of $\mathrm{Pb}$ in the pyrite ashes is crucial with respect to its potential health effects (Mejía, 1997; NLM, 2003). In this work, the principal $\mathrm{Pb}$-phases identified by FE-SEM, HR-TEM, EDS, FFT, SAED, and MBD include Pb-oxides at sizes of $<10 \mathrm{~nm}$ (e.g. massicot, Table 4), Pb-sulphate (e.g anglesite as isolated particles $\sim 50-300 \mathrm{~nm}$ in length), $\mathrm{Pb}$ encapsuled in carbonaceous matter, abundant amorphous minerals, and a $\mathrm{Pb}-\mathrm{As}$ phase (in a $\sim 25-\mathrm{nm}$ particle). Almost all the identified $\mathrm{Pb}$-bearing phases are in the respirable particle size category. Our results emphasize the need for detailed single-particle characterization of anthropogenic nanoparticles and secondary nanominerals emitted from the sulphuric acid production industry based on pyrite utilization.

\section{CONCLUSIONS}

The results of the present work provide evidence the complexity of the chemistry and mineralogical composition of nanoparticles in abandoned sulphuric acid industry by-products. Iron-rich nanoparticles often contain high proportions of toxic elements such as As, Se, U and others. A number of elements, such as $\mathrm{As}, \mathrm{Cr}, \mathrm{Cu}, \mathrm{Co}, \mathrm{La}, \mathrm{Mn}, \mathrm{Ni}, \mathrm{Pb}, \mathrm{Sb}, \mathrm{Se}, \mathrm{Sr}, \mathrm{Ti}, \mathrm{Zn}$, and $\mathrm{Zr}$, were found to be present in individual nanoparticles and nanominerals (e.g. oxides, sulphates, clays) in concentrations up to 5\%. Further research will include an in-depth assessment of evaluate the solubility of these residues, with views of a study on the toxicological risks for lung DNA and cells of human beings and other organisms likely to be exposed to them. In addition, the reductions in mobility, toxicity, and bioavailability associated with sorption, combined with the enhanced uptake expected of nanophases, provide considerable incentive to further explore the role that nanoparticulate minerals play in the attenuation of contaminant species in the environment. Future work will improve the conditions that would optimize this retention, and assess the possibility of reusing pyrite ashes as sorbents.

\section{Acknowledgements}

The research for this study was carried out with support from the Catarinense Institute of Environmental Research and Human Development (IPADHC). The authors thank to the CNPq, 
FAPERGS, and Electron Microscopy Center of the Federal University of Rio Grande do Sul for the analyses. Marcos L. S. Oliveira and Luis Silva benefited from a scholarship financed by CNPq, Brazil Ref: 382954/2011-4 and Processo: 380649/2011-0.

\section{References}

Borda M, Elsetinow A, Schoonen M, Strongin D. Pyrite-induced hydrogen peroxide formation as a driving force in the evolution of photosynthetic organisms on an early Earth. Astrobiology 2001; 1: 283-8.

Brown DM, Wilson MR, MacNee W, Stone V, Donaldson K. Size-Dependent Proinflammatory Effects of Ultrafine Polystyrene Particles: A Role for Surface Area and Oxidative Stress in the Enhanced Activity of Ultrafines. Toxicol Appl Pharmacol 2001; 175: 191-9.

Chen Y, Shah N, Huggins FE, Huffman GP. Investigation of the microcharacteristics of PM2.5 in residual oil fly ash by analytical transmission electron microscopy. Environ Sci Technol 2004; 38: 6553-60.

Cohn CA, Borda MJ, Schoonen MA. RNA decomposition by pyrite-induced radicals and possible role of lipids during the emergence of life. Earth Planet Sci Letters 2004; 225: 271-8.

Cohn CA, Pak A, Schoonen MA, Strongin DR. Quantifying hydrogen peroxide in iron-containing solutions using leuco crystal violet. Geochem Trans 2005; 6: 47-52.

Cornell RM, Schwertmann U. The Iron Oxides: Structure, Properties, Reactions, Occurrence and Uses, second, completely revised and extended ed. Weinheim: Wiley-VCH Verlag GmbH \& Co. KGaA; 2003.

Devasahayam S. Chemistry of acid production in black coal mine washery wastes, Int J Miner Process 2006; 79: 1-8.

Feng, J. Y., Hu, X. J., \& Yue, P. L. Discoloration and mineralization of orange II using different heterogeneous catalysts containing Fe: A comparative study. Environmental Science \& Technology 2004; 38: 5773-5778.

Finkelman RB. Modes of occurrence of potentially hazardous elements in coal: levels of confidence, Fuel Process Technol 1994; 39: 21.

Finkelman RB, Gross PMK. The types of data needed for assessing the environmental and human health impacts of coal. Int J Coal Geol 1999; 40: 91-101. 
Frazier AW, Lehr JR, Dillard EF. Chemical behaviour of fluorine in production of wet-process phosphoric acid. Environ Sci Technol 1977; 11: 1007-14.

Galatto SL, Peterson M, Alexandre NZ, da Costa JAD, Izidoro G, Sorato L., et al. Incorporação de resíduo do tratamento de drenagem ácida em massa de cerâmica vermelha. Cerâmica 2009; 55: 5360.

GASPETRO http://www.gaspetro.com.br/objects/files/2004-11/70_rel_icc_2001.pdf. Access June 2010.

Giere R, Blackford M, Smith K. TEM Study of PM2.5 Emitted from Coal and Tire Combustion in a Thermal Power Station. Environ Sci Technol 2006; 40: 6235-40.

Gupta SK, Vollmer MK, Krebs R. The importance of mobile, mobilisable and pseudo-total heavy metal fractions in soil for three-level risk assessment and risk management. Sci Total Environ 1996; 178: $11-20$.

Hochella M, Lower S, Maurice P, Penn L, Sahai N, Sparks D, Twining B. Nanominerals, Mineral Nanoparticles, and Earth Systems. Science 2008; 319: 1631-5.

Hower JC, Graham U, Dozier A, Tseng M, Khatri R. Association of the sites of heavy metals with nanoscale carbon in a kentucky electrostatic precipitator fly ash. Environ Sci Technol 2008; 42: 8471-7.

International Center for Diffraction Data (ICDD). http://www.icdd.com. Access: 20 July 2010.

Kawatra SK, Ripke SJ, Pelletizing steel mill desulfurization slag. Int J Miner Process 2002; 65: 165-75.

Lattuada RM, Menezes CTB, Pavei PT, Peralba MCR, Dos Santos JHZ. Determination of metals by total reflection X-ray fluorescence and evaluation of toxicity of a river impacted by coal mining in the south of Brazil. J Hazard Mater 2009; 163: 531-7.

Lin ZX, Qvarfort U. Predicting the mobility of $\mathrm{Zn}, \mathrm{Fe}, \mathrm{Cu}, \mathrm{Pb}, \mathrm{Cd}$ from roasted sulfide (pyrite) residuesA case study of wastes from the sulfuric acid industry in Sweden. Waste Manage 1996; 16: 671-81.

Madden AS, Hochella, M. F., Luxton, TP. Insights for size-dependent reactivity of hematite nanomineral surfaces through $\mathrm{Cu}^{2+}$ sorption. Geochimica et Cosmochimica Acta 2006; 70: 40954104.

Marcello RR, Galatob S, Petersona M, Riellac HG, Bernardin AM. Inorganic pigments made from the recycling of coal mine drainage treatment sludge. J Environ Manage 2008; 88: 1280-4.

Mathew M, Takagi S, Waerstad KR, Frazier AW. The crystal structure of synthetic chukhrovite $\mathrm{Ca}_{4} \mathrm{AlSi}\left(\mathrm{SO}_{4}\left(\mathrm{~F}_{13}-12 \mathrm{H}_{2} \mathrm{O}\right.\right.$. Am Mineral 1981: 66: 392-7. 
Mejía JJ, Díaz-Barriga F, Calderón J, Ríos C, Jiménez-Capdeville ME. Neurotoxicol Teratol 1997; 19: 489-97.

NLM. TOXNET. 2003. National Library of Medicine. http:// www.toxnet.nlm.nih.gov.

Oliveira MLS, Ward CR, French D, Hower JC, Querol X, Silva LFO. Mineralogy and leaching characteristics of beneficiated coal products from Santa Catarina, Brazil. Int J Coal Geol 2012 in press doi: 10.1016/j.coal.2011.10.004

Pérez-López R, Sáez R, Álvares-Valero AM, Nieto JM, Pace G, Combination of sequential chemical extraction and modelling of dam-break wave propagation to aid assessment of risk related to the possible collapse of a roasted sulphide tailings dam. Sci Total Environ 2009; 407: 5761-71.

Pires M, Querol X. Characterization of Candiota (South Brazil) coal and combustion byproduct. Int J Coal Geol 2004; 60: 57-72.

Querol X, Whateley MKG, Fernandez-Turiel JL, Tuncali E. Geological controls on the mineralogy and geochemistry of the Beypazari lignite, central Anatolia, Turkey. Int J Coal Geol 1997; 33: 255-71.

Quispe D, Pérez-López R, Silva LFO, Nieto JM. Changes in mobility of hazardous elements during coal combustion in Santa Catarina power plant (Brazil). Fuel 2012 in press doi:10.1016/j.fuel.2011.09.034

Rao CP, Gluskoter HJ. Occurrence and distribution of minerals in Illinois coals. Illinois State Geological Survey Circular 1973; 476: 56.

Ribeiro J, Flores D, Ward CR, Silva LFO. Identification of nanominerals and nanoparticles in burning coal waste piles from Portugal. Sci Total Environ 2010; 408: 6032-41.

Rico M, Benito G, Salgueiro AR, Díez-Herrero A, Pereira HG. Reported tailings dam failures: A review of the European incidents in the worldwide context. J Hazard Mater 2008a; 152: 846-52.

Rico M, Benito G, Díez-Herrero A. Floods from tailings dam failures. J Hazard Mater 2008b; 154: 7987.

Rietveld HM. A profile refinement method for nuclear and magnetic structures. J Appl Crystallogr 1969; 2: $65-71$.

Rutherford PM, Dudas MJ, Samek RA. Environmental impacts of phosphogypsum. Sci Total Environ 1994; 149: 1-38.

Sakurovs R, French D, Grigore M. Quantification of mineral matter in commercial cokes and their parent coals. Int J Coal Geol 2007; 72: 81-8.

Salomons W. Environmental impact of metals derived from mining activities: processes, predictions, prevention. J Geochem Explor 1995; 52: 5-23. 
Seredin VV, Dai S. Coal deposits as potential alternative sources for lanthanides and yttrium. Int J Coal Geol; 2012 in press doi:10.1016/j.coal.2011.11.001

Sherman D. M. Electronic structures of iron(III) and manganese(IV) (hydr)oxide minerals:

Thermodynamics of photochemical reductive dissolution in aquatic environments. Geochimica et Cosmochimica Acta 2005; 69: 3249-3255.

Silva LFO, DaBoit K. Nanominerals and nanoparticles in feed coal and bottom ash: implications for human health effects. Environ Monit Assess 2010; 174: 187-97.

Silva LFO; Moreno T, Querol X. An introductory TEM study of Fe-nanominerals within coal fly ash. Sci Total Environ 2009; 407: 4972-4.

Silva LFO, Hower JC, Izquierdo M, Querol X. Complex nanominerals and ultrafine particles assemblages in phosphogypsum of the fertilizer industry and implications on human exposure. Sci Total Environ 2010a; 408: 5117-22.

Silva LFO, Macias F, Oliveira MLS, Da Boit KM, Waanders F. Coal Cleaning Residues and Feminerals Implications. Environ Monit Assess 2010b; 172: 367-78.

Silva LFO, Wollenschlager M, Oliveira MLS. A preliminary study of coal mining drainage and environmental health in the Santa Catarina region, Brazil. Environ Geochem Health 2010c; 33: 55-5.

Silva LFO, Izquierdo M, Querol X, Finkelman RB, Oliveira MLS, Wollenschlager M, Towler M, PérezLópez R, Macias F. Leaching of potential hazardous elements of Coal Cleaning Rejects. Environ Monit Assess 2011; 175: 109-26.

Silva LFO, DaBoit KM, Sampaio CH, Jasper A, Andrade ML, Kostova IJ, Waanders FB, Henke KR, Hower JC. The occurrence of hazardous volatile elements and nanoparticles in Bulgarian coal fly ashes and the effect on human health exposure. Sci Total Environ 2012; 416: 513-26.

Taylor JC. Computer programs for standardless quatitative analysis of minerals using the full powder diffraction profile. Powder Diffr 1991; 6: 2-9.

Utsunomiya S, Jensen KA, Keeler GJ, Ewing RC, Direct Identification of Trace Metals in Fine and Ultrafine Particles in the Detroit Urban Atmosphere. Environ Sci Technol 2004; 38: 2289-97.

Ward CR, Spears DA, Booth CA, Staton I, Gurba LW. Mineral matter and tace elements in coals of the Gunnedah Basin, New South Wales, Australia. Int J Coal Geol 1999; 40: 281-308.

Waychunas G, Kim C, Banfield J. Nanoparticulate iron oxide minerals in soils and sediments: Unique properties and contaminant scavenging mechanisms. Journal of Nanoparticle Research 2005a; 7: 409-433. 
Waychunas G, Trainor T, Eng P, Catalano J, Brown G, Davis J. Surface complexation studied via combined grazing-incidence EXAFS and surface diffraction: Arsenate and hematite $\left(\begin{array}{llll}0 & 0 & 0 & 1\end{array}\right)$ and $\left(\begin{array}{ll}1\end{array}\right.$ 0-1 2). Analytical and Bioanalytical Chemistry 2005b; 383: 12-27.

Weber PA, Skinner WM, Hughes JB, Lindsay P, Moore TA. Source of Ni in coal mine acid rock drainage, West Coast, New Zealand. Int J Coal Geol 2006; 67: 214-20.

Zeilinski RA, Al-Hwaiti MS, Budahn JR, Ranville JF, Radionuclides, trace elements, and radium residence in phosphogypsum of Jordan. Environ Geochem Health 2010; 33: 149-65.

Zouboulis AI, Kydros KA, Matis KA. Removal of toxic metal ions from solutions using industrial solid byproducts. Water Sci Technol 1993; 27: 83-93. 
Table 1: Mineralogy of pyrite concentrate (IM-05) and pyrite ash samples as indicated by X-ray diffraction and Siroquant.

\begin{tabular}{lrrrrrr} 
& I M-05 & I M-10 & I M-1 I & I M-12 & I M-13 & I M- 14 \\
\hline wt \% & 1.9 & 2.6 & 1.6 & 3.2 & 2.5 & 1.4 \\
$\begin{array}{l}\text { Quartz } \\
\text { Kaolinite }\end{array}$ & 4.2 & & & & & \\
IIlite & & & 2.8 & & & \\
Gypsum & 34.0 & 16.1 & 1.9 & 8.6 & 2.6 & 4.1 \\
Hematite & & 81.3 & 78.0 & 74.0 & 92.4 & 73.3 \\
Magnetite & & & 14.6 & 12.7 & & 19.9 \\
Pyrite & 39.4 & & & & & \\
Jarosite & & & 1.1 & 1.6 & 2.5 & 1.3 \\
Coquimbite & 6.6 & & & & & \\
Szomolnockite & 13.8 & & & & & \\
\hline
\end{tabular}

Table 2: Inferred chemistry (wt \%) from XRD data for pyrite concentrate (IM-05) and pyrite ash samples

\begin{tabular}{lrrrrrr} 
& I M-05 & I M-10 & I M-11 & I M-12 & I M-13 & I M-14 \\
\hline Al & 0.73 & & 0.53 & & & \\
$\mathbf{C a}$ & 6.83 & 3.75 & 0.44 & 2.00 & 0.61 & 0.95 \\
$\mathbf{F e}$ & 20.53 & 56.85 & 65.12 & 61.10 & 65.45 & 65.61 \\
$\mathbf{K}$ & & & 0.30 & 0.12 & 0.20 & 0.10 \\
$\mathbf{M g}$ & & & & & & \\
$\mathbf{N a}$ & & & & & & \\
$\mathbf{P}$ & & & & & & \\
$\mathbf{S}$ & & & & & & \\
$\mathbf{S i}$ & 1.51 & 1.22 & 1.41 & 1.49 & 1.17 & 0.65 \\
$\mathbf{T i}$ & & & & & & \\
\hline
\end{tabular}


Table 3: Chemical analysis data for pyrite concentrate (IM-05) and pyrite ash samples. Range of concentrations are also indicated for coal cleaning rejects from Santa Catarina (Silva et al., 2011), and for ore-derived roasted pyrite materials (Li and Qvafort, 1996; Perez-Lopez et al., 2009).

\begin{tabular}{|c|c|c|c|c|c|c|c|c|c|c|c|c|}
\hline & \multicolumn{4}{|c|}{ Phosphogypsum } & \multirow{2}{*}{$\begin{array}{c}\begin{array}{c}\text { Pyrite } \\
\text { concentrate }\end{array} \\
\text { IM-05 }\end{array}$} & \multicolumn{5}{|c|}{ Roasted pyrite ash } & \multirow[t]{2}{*}{$\begin{array}{r}\text { Coal } \\
\text { cleaning } \\
\text { rejects }\end{array}$} & \multirow[t]{2}{*}{$\begin{array}{r}\text { Ore-derived } \\
\text { roasted } \\
\text { pyrite }\end{array}$} \\
\hline$\%$ & IM-01 & IM-02 & IM-03 & IM-04 & & IM10 & IM11 & IM12 & IM13 & IM14 & & \\
\hline Al & 0.16 & 0.18 & 0.12 & 0.11 & 1.0 & 1.0 & 1.4 & 2.0 & 1.4 & 1.4 & $7-12$ & $0.17-3.7$ \\
\hline $\mathrm{Ca}$ & 28.82 & 24.32 & 24.21 & 24.85 & 3.8 & 3.4 & 0.08 & 0.3 & 0.4 & 0.3 & $0.06-2$ & $0.11-3$ \\
\hline $\mathrm{Fe}$ & 0.52 & 0.65 & 0.72 & 0.64 & 25 & 51 & 55 & 51 & 52 & 55 & $0.7-5$ & $47-63$ \\
\hline K & $<0.01$ & $<0.01$ & $<0.01$ & $<0.01$ & 0.1 & 0.1 & 0.2 & 0.3 & 0.2 & 0.2 & $1-3$ & $0.02-1.1$ \\
\hline Mg & 0.03 & 0.04 & 0.02 & 0.03 & 0.02 & 0.02 & 0.02 & 0.02 & 0.03 & 0.02 & $0.1-0.6$ & $0.09-1.1$ \\
\hline $\mathrm{Na}$ & 0.02 & 0.02 & 0.02 & 0.02 & 0.03 & 0.07 & 0.05 & 0.05 & 0.05 & 0.04 & $0.08-0.4$ & $0.04-0.6$ \\
\hline $\mathbf{P}$ & 0.28 & 0.32 & 0.35 & 0.62 & 0.1 & 0.75 & 0.05 & 0.04 & 0.04 & 0.09 & $0.01-0.03$ & $0.006-0.06$ \\
\hline $\mathbf{S}$ & 17.8 & 17.38 & 17.67 & 1.25 & 27 & 3.1 & 0.5 & 0.7 & 0.6 & 0.8 & $0.5-5$ & $0.13-8$ \\
\hline $\mathrm{Ti}$ & 0.31 & 0.4 & 0.27 & 0.32 & 0.1 & 0.1 & 0.07 & 0.09 & 0.06 & 0.05 & $0.4-0.7$ & $0.01-0.5$ \\
\hline $\mathrm{mg} / \mathrm{kg}$ & IM-01 & IM-02 & IM-03 & IM-04 & IM-05 & IM10 & IM11 & IM12 & IM13 & IM14 & $\begin{array}{r}\text { Coal } \\
\text { cleaning } \\
\text { rejects }\end{array}$ & $\begin{array}{r}\text { Ore-derived } \\
\text { roasted } \\
\text { pyrite }\end{array}$ \\
\hline $\begin{array}{l}\text { As } \\
\text { B }\end{array}$ & $<0.1$ & $<0.1$ & $<0.1$ & $<0.1$ & $\begin{array}{r}75 \\
<0.1\end{array}$ & $\begin{array}{r}136 \\
<0.01\end{array}$ & $\begin{array}{r}270 \\
<0.01\end{array}$ & $\begin{array}{r}223 \\
<0.01\end{array}$ & $\begin{array}{r}189 \\
<0.01\end{array}$ & $\begin{array}{r}250 \\
<0.01\end{array}$ & $\begin{array}{l}6-44 \\
5-23\end{array}$ & $4175-13240$ \\
\hline
\end{tabular}




\begin{tabular}{|c|c|c|c|c|c|c|c|c|c|c|c|c|}
\hline $\mathrm{Ba}$ & 1537 & 1361.7 & 767.1 & 877.8 & 326 & 395 & 405 & 244 & 296 & 79 & $301-1806$ & \\
\hline $\mathrm{Be}$ & 1.1 & 1.1 & 1.2 & 1.2 & $<0.1$ & 4.3 & $<0.01$ & $<0.01$ & $<0.01$ & $<0.01$ & $2-5$ & \\
\hline $\mathbf{B i}$ & & & & & $<0.1$ & $<0.01$ & $<0.01$ & $<0.01$ & $<0.01$ & $<0.01$ & $1-2$ & $28-228$ \\
\hline $\mathrm{Cd}$ & $<0.1$ & $<0.1$ & $<0.1$ & $<0.1$ & $<0.1$ & 2 & 1 & $<0.01$ & $<0.01$ & $<0.01$ & $1-2$ & $20-161$ \\
\hline $\mathrm{Ce}$ & 2546.4 & 2511 & 2462.3 & 2109.1 & 108 & 32 & 47 & 17 & 13 & 47 & $71-123$ & \\
\hline Co & 2.0 & 2.4 & 1.8 & 2.3 & 11 & 31 & 51 & 38 & 39 & 47 & $1-13$ & $76-260$ \\
\hline $\mathrm{Cr}$ & 11.1 & 13.6 & 14.7 & 14.2 & 18 & 18 & 11 & 11 & 10 & 13 & $39-57$ & $18-112$ \\
\hline Cs & $<0.1$ & $<0.1$ & $<0.1$ & $<0.1$ & 1 & 1 & 1 & 2 & 1 & 1 & $11-26$ & \\
\hline $\mathrm{Cu}$ & 6.3 & 6.9 & 7.2 & 7.4 & 79 & 91 & 131 & 114 & 110 & 174 & $14-40$ & $1490-5823$ \\
\hline Dy & 28.5 & 28.5 & 26.5 & 26.2 & 2.1 & 5 & 1 & $<0.01$ & $<0.01$ & $<0.01$ & $4-6$ & \\
\hline Er & 7.5 & 7.6 & 7.0 & 6.7 & $<0.1$ & 2 & $<0.01$ & $<0.01$ & $<0.01$ & $<0.01$ & $2-3$ & \\
\hline Eu & 25.6 & 25.9 & 23.7 & 24 & 1.3 & 3 & $<0.01$ & $<0.01$ & $<0.01$ & $<0.01$ & $<1-1.2$ & \\
\hline Ga & 10.9 & 10.4 & 10.2 & 9 & 3 & 4 & 3 & 5 & 3 & 4 & $23-32$ & \\
\hline Gd & 115.8 & 116.5 & 107.2 & 107.1 & 6 & 15 & 3 & 1 & 1 & 2 & $5-8$ & \\
\hline Ge & 2.1 & 2.1 & 2.0 & 1.9 & 3 & 7 & 3 & 2 & 2 & 5 & $3-5$ & \\
\hline Hf & 6.3 & 6.8 & 5.7 & 6.7 & 2 & 2 & $<1$ & $<1$ & 0.5 & $<0.01$ & $4-8$ & \\
\hline Ho & 3.8 & 3.8 & 3.5 & 3.4 & $<0.1$ & $<0.01$ & $<0.01$ & $<0.01$ & $<0.01$ & $<0.01$ & $<1-1.0$ & \\
\hline La & 990.5 & 980.2 & 923.7 & 921.1 & 49 & 126 & 19 & 7 & 5 & 30 & $29-48$ & \\
\hline Li & $<0.1$ & $<0.1$ & $<0.1$ & $<0.1$ & 5 & 3 & 7 & 18 & 6 & 46 & $50-120$ & \\
\hline Lu & $<0.1$ & $<0.1$ & $<0.1$ & $<0.1$ & $<0.1$ & $<0.01$ & $<0.01$ & $<0.01$ & $<0.01$ & $<0.01$ & $<1$ & \\
\hline
\end{tabular}




\begin{tabular}{|c|c|c|c|c|c|c|c|c|c|c|c|c|}
\hline Mn & 179.7 & 214.7 & 173.7 & 205.2 & 60 & 103 & 109 & 81 & 115 & 55 & $12-641$ & \\
\hline Mo & $<0.1$ & $<0.1$ & $<0.1$ & $<0.1$ & 11 & 16 & 23 & 19 & 19 & 22 & $3-7$ & \\
\hline $\mathrm{Nb}$ & 310.2 & 381.4 & 601.2 & 583.2 & 150 & 151 & 35 & 16 & 14 & 13 & $36-54$ & \\
\hline Nd & 1133.6 & 1144.6 & 1065.3 & 1069.4 & 53 & 140 & 19 & 7 & 6 & 10 & $29-51$ & \\
\hline $\mathrm{Ni}$ & 5.4 & 5.5 & 5.5 & 6.4 & 32 & 56 & 98 & 86 & 88 & 82 & $4-23$ & $29-726$ \\
\hline $\mathbf{P b}$ & 9 & 9.1 & 16 & 7.2 & 404 & 395 & 443 & 349 & 284 & 658 & $27-140$ & $2110-24170$ \\
\hline Pr & 273 & 276.2 & 257.9 & 256.1 & 12 & 35 & 5 & 2 & 1 & 3 & $7-12$ & \\
\hline $\mathbf{R b}$ & $<0.1$ & $<0.1$ & $<0.1$ & $<0.1$ & 6 & 9 & 9 & 13 & 9 & 8 & $58-142$ & \\
\hline $\mathrm{Sb}$ & $<0.1$ & $<0.1$ & $<0.1$ & $<0.1$ & 6 & 12 & 9 & 7 & 5 & 9 & $0.4-2$ & $0-788$ \\
\hline Sc & 2.8 & 3 & 2.6 & 3.1 & 2 & 3 & 2 & 2 & 1 & 2 & $10-20$ & \\
\hline Se & 19.1 & 19.1 & 18.6 & 16.6 & 15 & 531 & 15 & 104 & 10 & 17 & $4-9$ & \\
\hline Sm & 153.7 & 154.9 & 143.1 & 144.7 & 8 & 20 & 3 & 1 & 1 & 2 & $6-10$ & \\
\hline Sn & 0.7 & 0.7 & 0.8 & $<0.1$ & 1 & 2 & 1 & 1 & 1 & 1 & $4-6$ & $172-931$ \\
\hline $\mathrm{Sr}$ & 5068.9 & 5029.5 & 4968 & 4884.9 & 774 & 893 & 41 & 32 & 26 & 80 & $58-616$ & \\
\hline Ta & 2.6 & 3.2 & 4 & 7.7 & 44 & 41 & 8 & 7 & 6 & 5 & $4-6$ & \\
\hline Tb & 8.8 & 8.7 & 8.1 & 8.1 & $<0.1$ & 1.2 & $<0.01$ & $<0.01$ & $<0.01$ & $<0.01$ & $0.9-1$ & \\
\hline Th & 70.4 & 71.1 & 67.2 & 68.2 & 5 & 15 & 4 & 3 & 3 & 10 & $14-41$ & \\
\hline TI & $<0.1$ & $<0.1$ & $<0.1$ & $<0.1$ & 8 & 17 & 17 & 17 & 19 & 41 & $1.3-13$ & \\
\hline $\mathbf{U}$ & 4.4 & 4.4 & 4.1 & 4.4 & 1 & 3 & 1 & 1 & 1 & 1 & $4.8-17$ & \\
\hline v & 6.9 & 8 & 8.8 & 9.2 & 15 & 23 & 21 & 21 & 19 & 21 & $97-106$ & $3-132$ \\
\hline
\end{tabular}




\begin{tabular}{|c|c|c|c|c|c|c|c|c|c|c|c|c|}
\hline $\mathbf{w}$ & 1.5 & 1.5 & 1.6 & 1.5 & 2 & 6 & 5 & 9 & 11 & 2 & $6-8$ & \\
\hline $\mathbf{Y}$ & 104.8 & 105.3 & 93.7 & 90 & 8 & 19 & 6 & 5 & 4 & 6 & $18-27$ & \\
\hline $\mathrm{Yb}$ & 2.8 & 2.9 & 2.6 & 2.4 & $<0.1$ & $<0.01$ & $<0.01$ & $<0.01$ & $<0.01$ & $<0.01$ & $2-3$ & \\
\hline $\mathrm{Zn}$ & $<0.1$ & 4,4 & 85.1 & $<0.01$ & 61 & 172 & 206 & 163 & 133 & 204 & $14-297$ & $5635-25443$ \\
\hline $\mathrm{Zr}$ & 310.1 & 336.3 & 302.8 & 359.7 & 107 & 98 & 37 & 27 & 33 & 44 & $143-325$ & \\
\hline
\end{tabular}


Table 4: Mineral phases indicated in pyrite concentrate (IM-05) and pyrite ash samples by a combination of FE-SEM/EDS and HR-TEM/STEM/EDS/SEAD/MBD/FFT techniques

\section{Pyrite concentrate Roasted pyrite ash}

\begin{tabular}{|c|c|c|c|c|c|c|}
\hline & IM-05 & IM-10 & IM-11 & IM-12 & IM-13 & IM-14 \\
\hline \multicolumn{7}{|l|}{ Carbonates } \\
\hline Ankerite, $(\mathrm{Fe}, \mathrm{Ca}, \mathrm{Mg}) \mathrm{CO}_{3}$ & $x$ & & & & & \\
\hline Aragonite, $\mathrm{CaCO}_{3}$ & $x$ & & & & & \\
\hline Calcite, $\mathrm{CaCO}_{3}$ & $x$ & & & & & \\
\hline Dolomite, $\mathrm{CaMg}\left(\mathrm{CO}_{3}\right)_{2}$ & $x$ & & & & & \\
\hline Siderite, $\mathrm{FeCO}_{3}$ & $x$ & & & & & \\
\hline \multicolumn{7}{|l|}{ Oxides and hydroxides } \\
\hline Cerianite, $\mathrm{CeO}_{2}$ & & & $x$ & $x$ & & \\
\hline Chromite $\mathrm{FeCr}_{2} \mathrm{O}_{4}$ & & $x$ & & & & $x$ \\
\hline Gibbsite, $\mathrm{Al}(\mathrm{OH})_{3}$ & $x$ & $x$ & $x$ & & $x$ & \\
\hline Goethite, $\mathrm{Fe}(\mathrm{OH})_{3}$ & $x$ & & & & & \\
\hline Hematite, $\mathrm{Fe}_{2} \mathrm{O}_{3}$ & & $x$ & $x$ & $x$ & $x$ & $x$ \\
\hline Hercynite, $\mathrm{FeAl}_{2} \mathrm{O}_{4}$ & & $x$ & $x$ & $x$ & $x$ & $x$ \\
\hline Ilmenite, $\mathrm{FeTiO}_{3}$ & & $x$ & $x$ & $x$ & $x$ & $x$ \\
\hline Maghemite $\mathrm{\gamma}-\mathrm{Fe}_{2} \mathrm{O}_{3}$ & & & & $x$ & $x$ & $x$ \\
\hline Magnesioferrite, $\mathrm{MgFe}_{2} \mathrm{O}_{4}$ & & $x$ & & $x$ & & \\
\hline Magnetite, $\mathrm{Fe}_{3} \mathrm{O}_{4}$ & $x$ & & $x$ & $x$ & $x$ & $x$ \\
\hline Massicot, $\mathrm{PbO}$ & & $x$ & & $x$ & $x$ & $x$ \\
\hline Rosenbergite, $\mathrm{AlF}_{3} .3 \mathrm{H}_{2} \mathrm{O}$ & $x$ & $x$ & $x$ & $x$ & $x$ & $x$ \\
\hline Rutile, $\mathrm{TiO}_{2}$ & $x$ & $x$ & $x$ & $x$ & $x$ & $x$ \\
\hline Wuestite, FeO & & $x$ & $x$ & $x$ & $x$ & $x$ \\
\hline \multicolumn{7}{|l|}{ Phosphates } \\
\hline Brushite, $\mathrm{CaPO}_{3}(\mathrm{OH}) \cdot 2 \mathrm{H}_{2} \mathrm{O}$ & $x$ & $x$ & $x$ & $x$ & $x$ & $x$ \\
\hline Monazite, $(\mathrm{Ce}, \mathrm{La}, \mathrm{Th}, \mathrm{Nd}, \mathrm{Y}) \mathrm{PO}_{4}$ & $x$ & $x$ & $x$ & $x$ & & \\
\hline \multicolumn{7}{|l|}{ Silicates } \\
\hline Quartz, $\mathrm{SiO}_{2}$ & & & $x$ & & $x$ & $x$ \\
\hline Albite, $\mathrm{NaAlSiO}_{8}$ & $x$ & & & & & \\
\hline
\end{tabular}


Chlorite $(\mathrm{Mg}, \mathrm{Fe}, \mathrm{Al})_{6}(\mathrm{Si}$,

Al) $)_{4} \mathrm{O}_{10}(\mathrm{OH})_{8}$

Diopside, $\mathrm{CaMg}\left(\mathrm{SiO}_{3}\right)_{2}$

$x$

Hedenbergite, $\mathrm{CaFeSi}_{2} \mathrm{O}_{6}$

X $\quad X \quad x \quad x$

Illite, $\mathrm{K}_{1.5} \mathrm{Al}_{4}\left(\mathrm{Si}_{6.5} \mathrm{Al}_{1.5} \mathrm{O}_{20}(\mathrm{OH})_{4}\right.$

$\mathrm{K}$ feldspar, $\mathrm{KAISi}_{3} \mathrm{O}_{8}$

$\mathrm{X}$

Melilite, $\mathrm{CaAl}_{12} \mathrm{MgSi}_{3} \mathrm{O}_{14}$

$x$

$\mathrm{X}$

Microcline, $\mathrm{KAISi}_{3} \mathrm{O}_{8}$

$x$

Mullite, $\mathrm{Al}_{6} \mathrm{Si}_{2} \mathrm{O}_{13}$

$x$

Muscovite,

$(\mathrm{Ba}, \mathrm{K}) \mathrm{Al}_{2}\left(\mathrm{Si}_{3} \mathrm{Al}\right) \mathrm{O}_{10}(\mathrm{OH})_{2}$

Olivine, $\mathrm{MgFeSiO}_{4}$

Talc, $\mathrm{Mg}_{3} \mathrm{Si}_{4} \mathrm{O}_{14}(\mathrm{OH})_{2}$

$X$

Zircon, $\mathrm{ZrSiO}_{4}$

$x$

\section{Sulphates}

Anglesite, $\mathrm{PbSO}_{4}$

Anhydrite, $\mathrm{CaSO}_{4}$

$x$

Barite, $\mathrm{BaSO}_{4}$

Gypsum, $\mathrm{CaSO}_{4} \cdot 2 \mathrm{H}_{2} \mathrm{O}$

$\mathrm{X}$

Hexahydrite, $\mathrm{MgSO}_{4} \cdot 6 \mathrm{H}_{2} \mathrm{O}$

$x$

Jarosite, $\mathrm{KFe}^{3+}{ }_{3}\left(\mathrm{SO}_{4}\right)_{2}(\mathrm{OH})_{6}$

$x$

$\begin{array}{llll}X & X & X\end{array}$

Melanterite, $\mathrm{FeSO}_{4} \cdot 7 \mathrm{H}_{2} \mathrm{O}$

$x$

Rozenite, $\mathrm{FeSO}_{4} \cdot 4 \mathrm{H}_{2} \mathrm{O}$

$X$

Schwertmannite,

$\mathrm{Fe}^{3+}{ }_{16} \mathrm{O}_{16}(\mathrm{OH})_{12}\left(\mathrm{SO}_{4}\right)_{2}$

\section{Sulfides}

Chalcopyrite, $\mathrm{CuFeS}_{2}$

$\mathrm{X}$

X

Galena, PbS

$X$

Marcasite, $\mathrm{FeS}_{2}$

$x$

Pyrite, $\mathrm{FeS}_{2}$

$X$

$\mathrm{X}$

Pyrrhotite $\mathrm{Fe}_{(1-x)} \mathrm{S}$

$x$

Sphalerite, ZnS

$\mathrm{X}$

$X$

$\mathrm{X}$ 


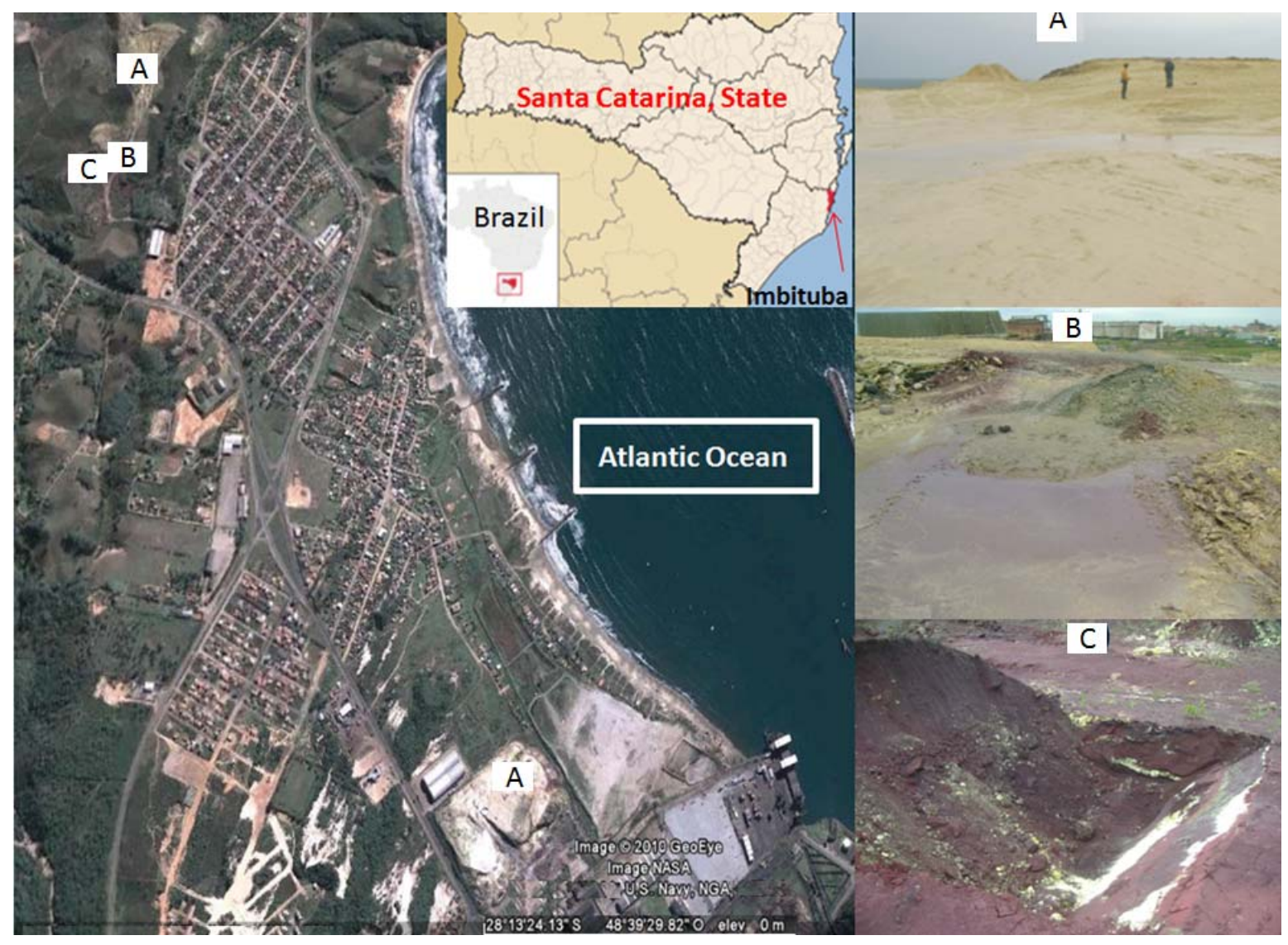

Figure 1: Location of the abandoned ICC complex in Santa Catarina, southern Brazil and representative illustrations of the waste piles sampled (A) phosphogypsum; (B) mixed concentrated pyrite, iron oxide, and phosphogypsum; (C) iron oxide containing secondary minerals (green fluorescence). 


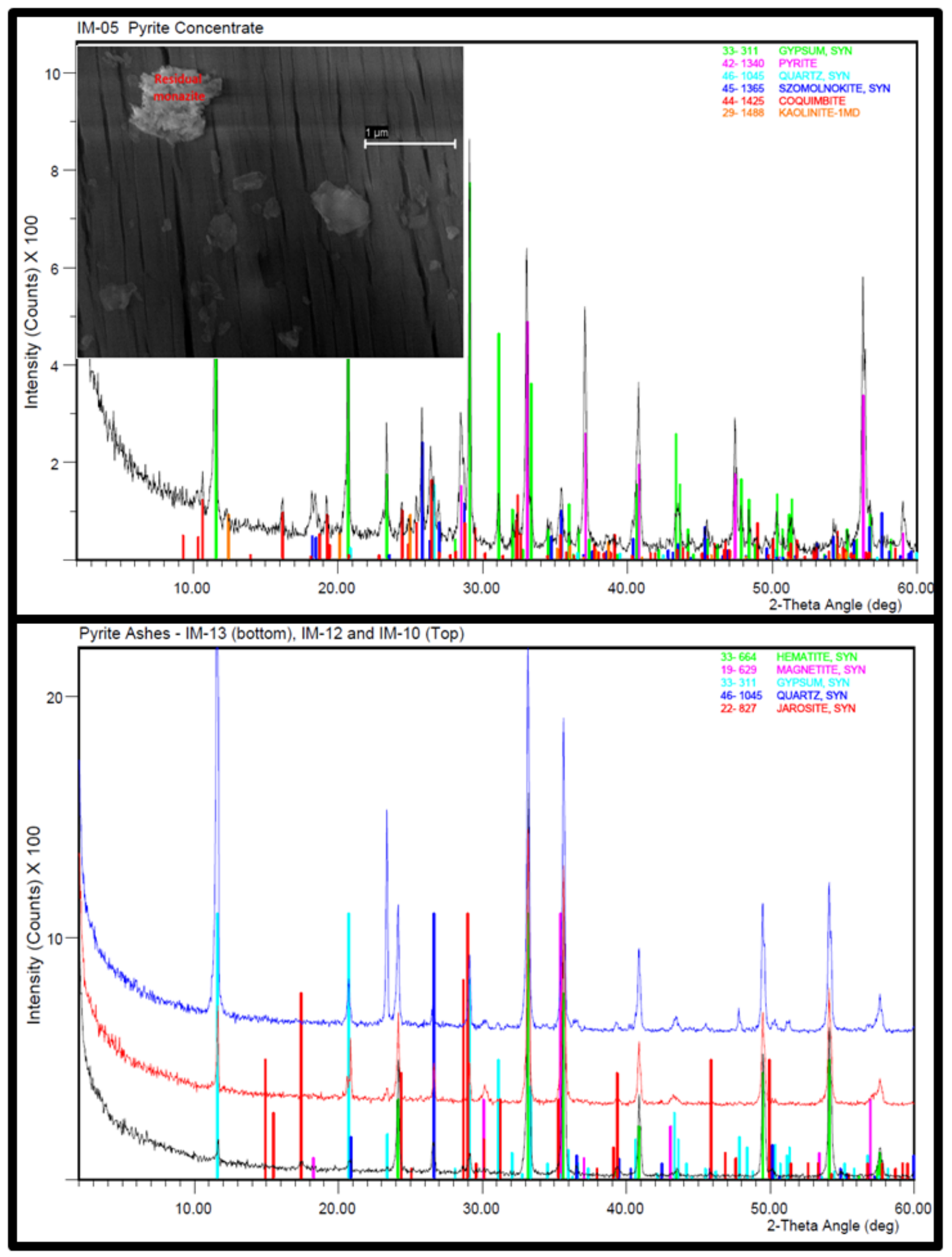

Figure 2: X-ray diffractograms of pyrite concentrate (IM-05, top) and selected pyrite ash samples (IM-10, IM12 and IM-13). 

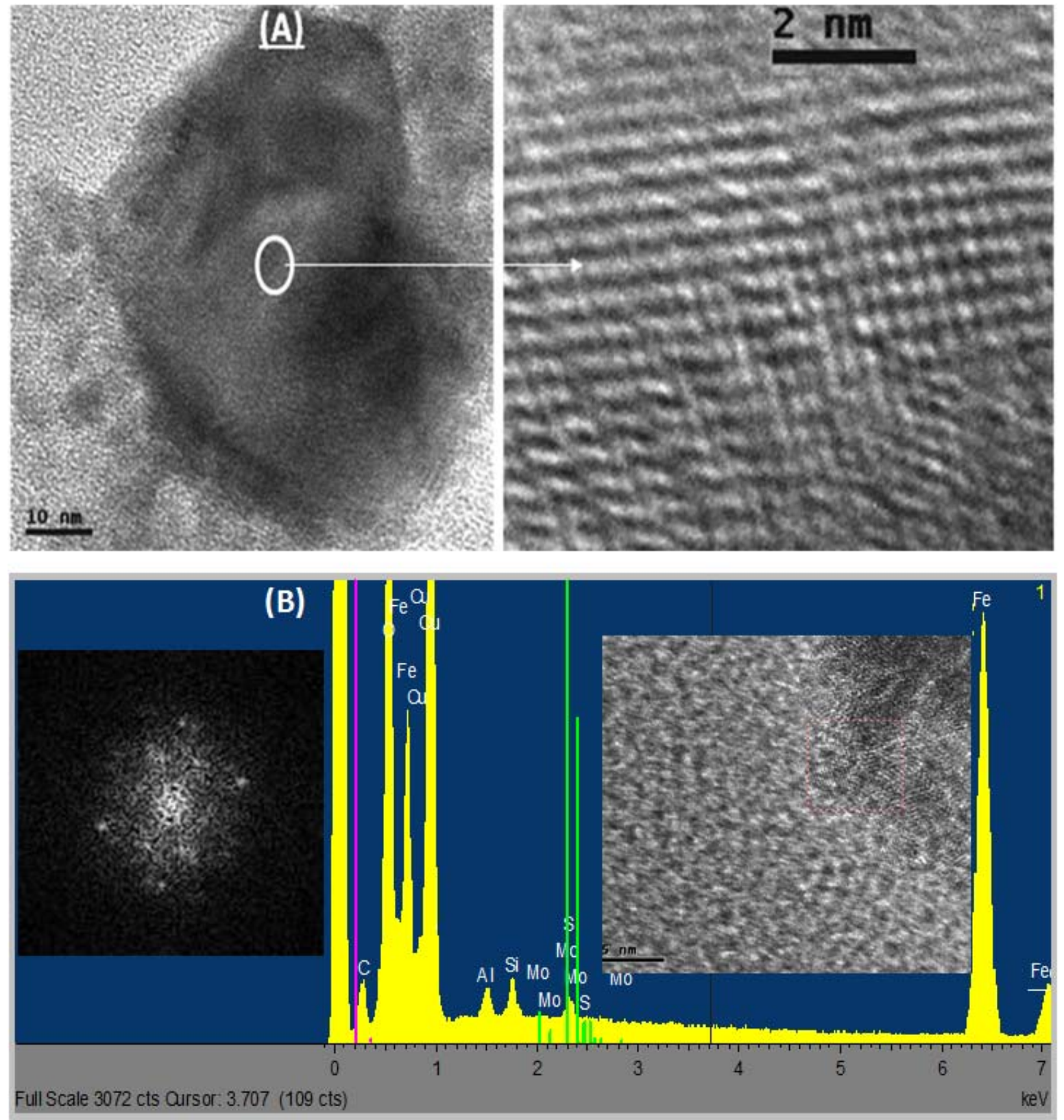

Figure 3: Illustrations of nanominerals detected in pyrite ash. (A) Magnetite and hematite mixed with carbonaceous aggregate from sample IM 12; (B) Hematite grains with FFT and EDS (sample IM 14) of the red section of the micrograph was scanned. 

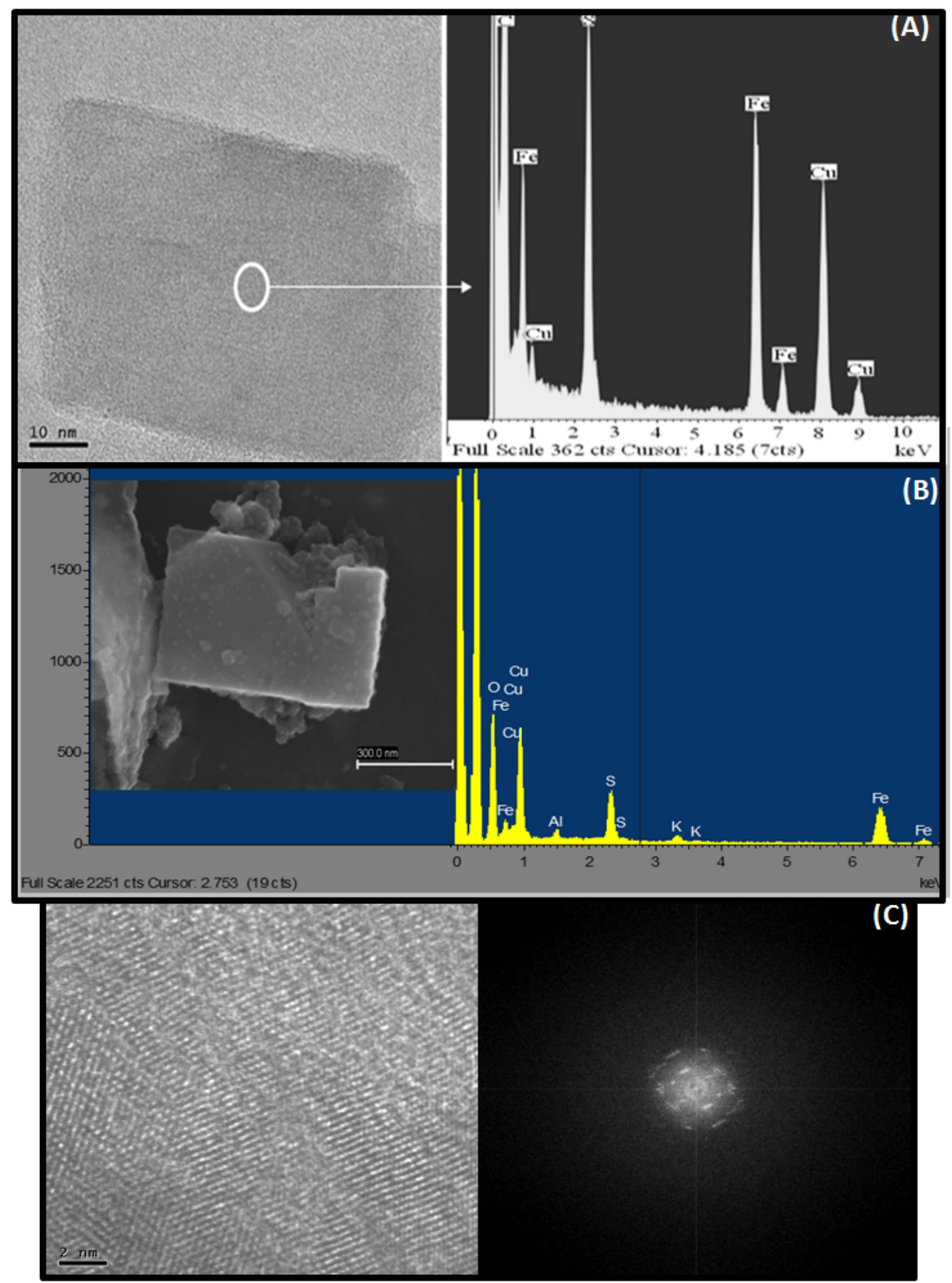

Figure 4: (A) Nanopyrite; (B) Jarosite pseudomorph with EDS; (C) Nanosphalerite with FFT to confirm structure (EDS spectrum includes Cu from grid). 


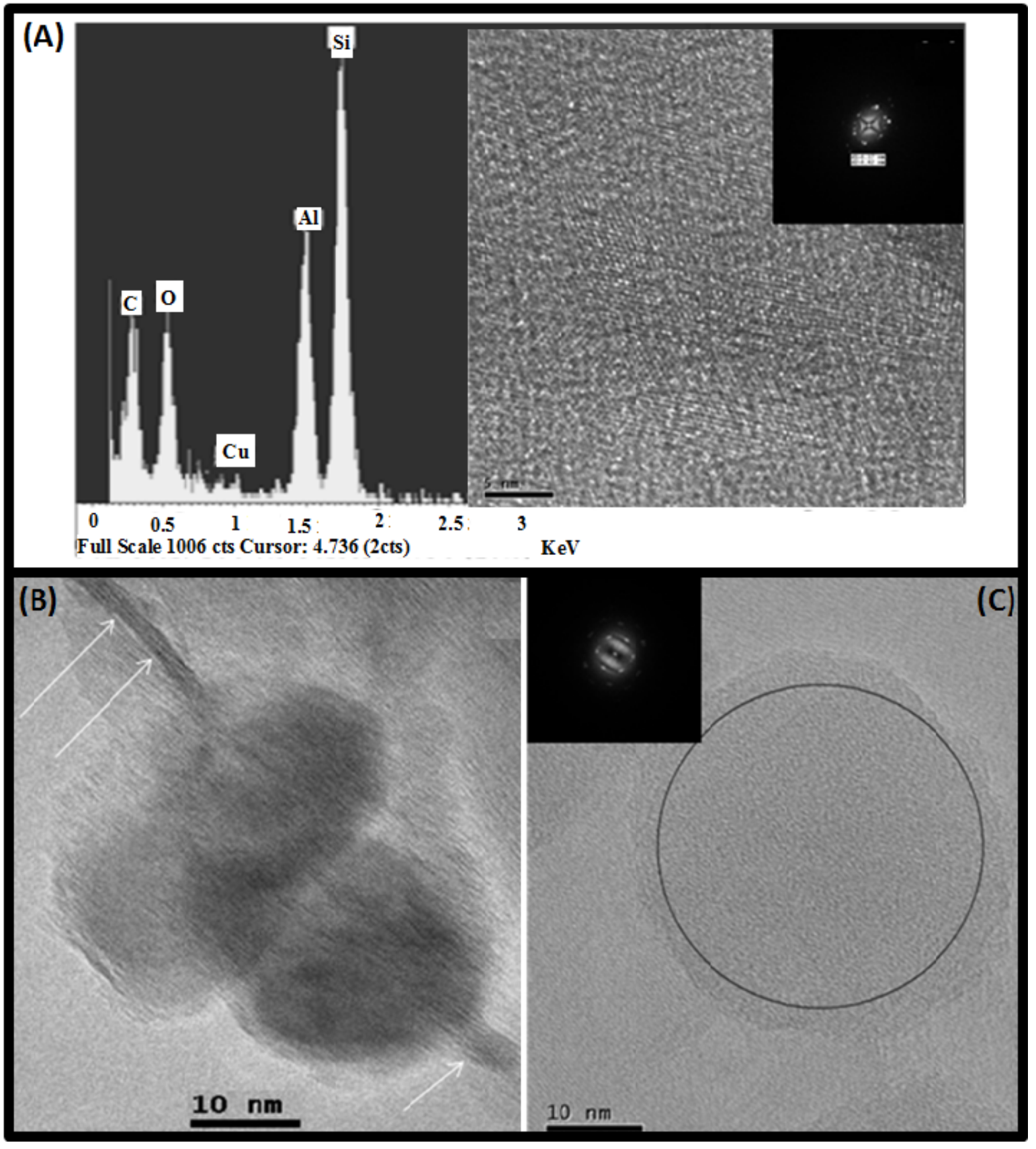

Figure 5: General illustrations of nanostructures in pyrite ashes (A) HR-TEM, EDS, and Fourier transformation (FFT) confirm the structure of kaolinite nanoparticles inside submicron spheres (EDS spectrum includes Cu from Grid); (B)HR-TEM image of carbonaceous nanoparticles in interaction with nanohematite crystals detected by EDS, SAED and MBD; (C) Quartz inside submicron spheres confirmed by FFT. 


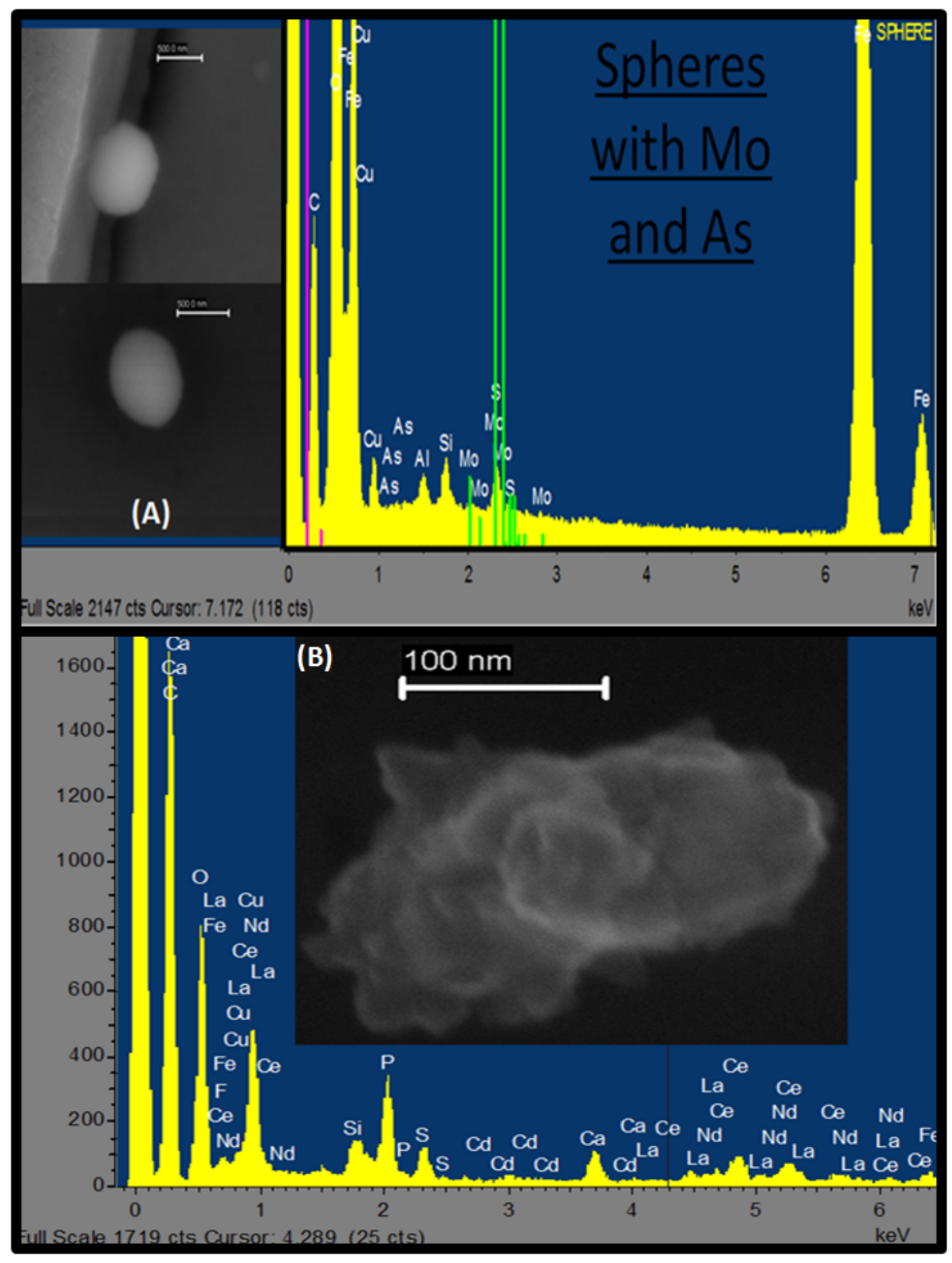

Figure 6: (A) Potentially toxic elements in ultra-fine amorphous particles (IM-10); (B) Ultra-fine particle of mixed residual monazite and apatite $\left(\mathrm{Ca}_{5} \mathrm{~F}\left(\mathrm{PO}_{4}\right)_{3}\right)$ containing $\mathrm{Cd}$ in a phosphosgypsum particle in sample IM 13 (EDS spectrum includes Cu from grid); 


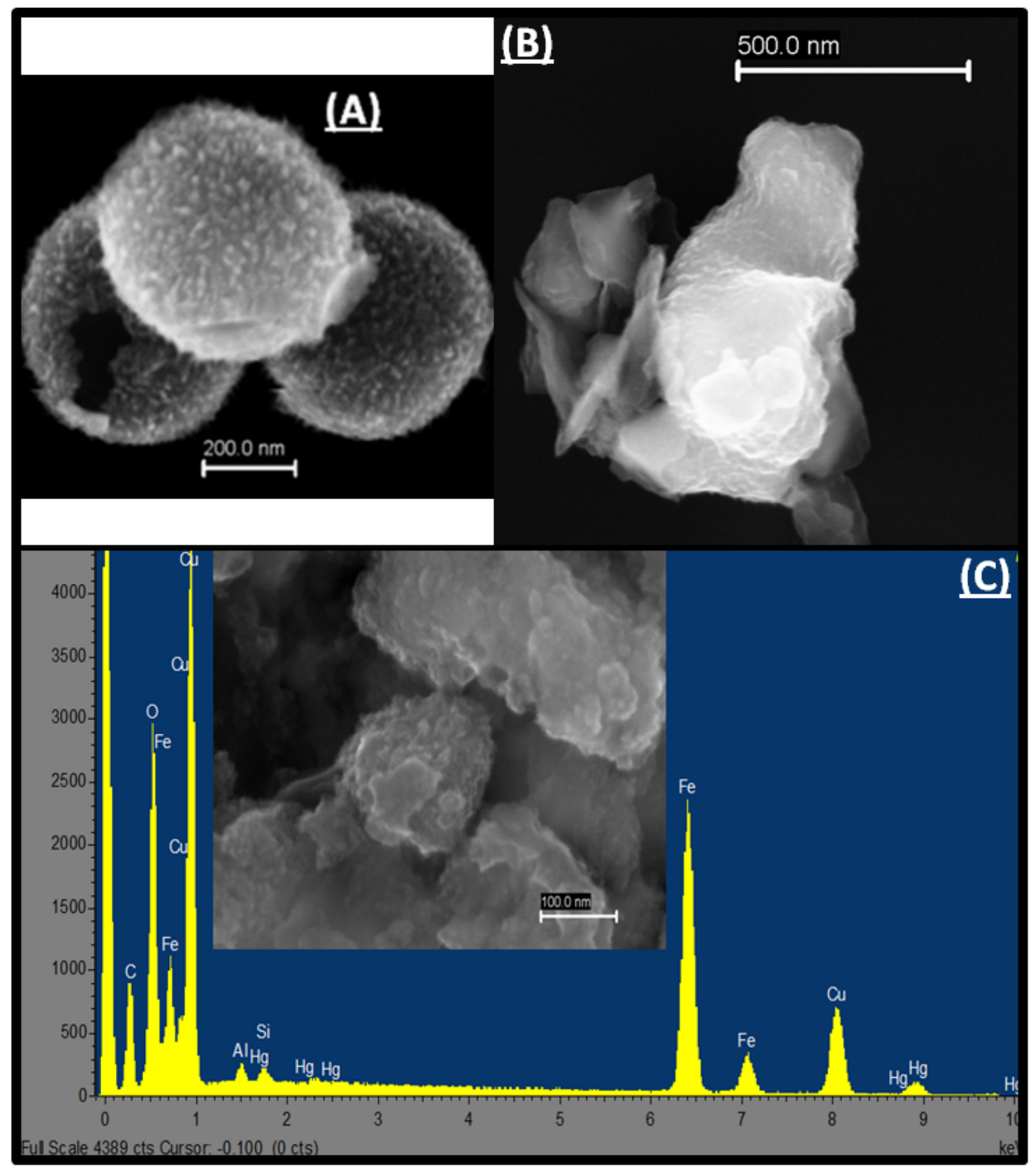

Figure 7: (A) Amorphous submicron spheres with high $\mathrm{Al}, \mathrm{Mg}, \mathrm{Ni}, \mathrm{O}$, and $\mathrm{Zr}$ concentrations; (B) $\mathrm{Fe}, \mathrm{Al}, \mathrm{Si}$ bearing glass phases; (C) Amorphous Fe nanominerals containing Hg (EDS spectrum includes Cu from grid). 